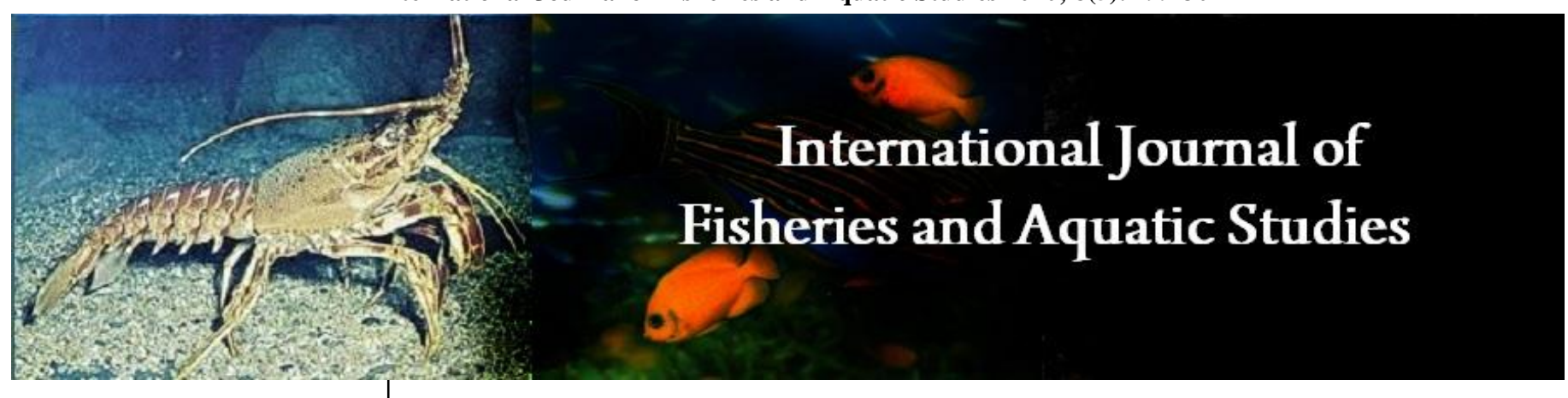

E-ISSN: 2347-5129

P-ISSN: 2394-0506

(ICV-Poland) Impact Value: 5.62

(GIF) Impact Factor: 0.549

IJFAS 2020; 8(5): 299-307

(C) 2020 IJFAS

www.fisheriesjournal.com

Received: 22-06-2020

Accepted: 19-08-2020

S Ramachandran

Fishery Survey of India,

Kochangadi, P.B.No.853, Kochi,

Kerala, India

L Ramalingam

Fishery Survey of India, 2nd

Floor Plot No.2A, Unit No.12,

New Fishing Harbour, Sassoon

Dock Colaba Mumbai

Maharashtra, India

\section{Population dynamics of spinycheek grouper Epinephelus diacanthus (Valenciennes, 1828) from the southwest coast of India}

\section{S Ramachandran and L Ramalingam}

DOI: $\underline{\text { https://doi.org/10.22271/fish.2020.v8.i5d.2337 }}$

\begin{abstract}
Subtle bathymetric distribution of Epinephelus diacanthus as a function of age was observed during the exploratory survey conducted for the past 20 years (2000-2019) by deploying different fishing gears such as bottom trawl, perch trap, bottom set vertical line and hand line suitable for various niche from Muddy to rocky bottom. The juveniles and the individuals of maturing stages of less than 3 years age groups occupies predominantly in the shallow muddy areas and sporadically occurs in the neighbor rocky with sandy grounds. However, the larger specimens of more than 3 years age groups occupies exclusively the rocky habitat of the depth between $60-110 \mathrm{~m}$. Moreover the larger size above $30 \mathrm{~cm}$ total length of above 3 years age group was not recorded from shallow muddy grounds during the past 20 years survey is imperative. The Population parameters of $E$. diacanthus were estimated from length frequency data through ELEFAN I (FISAT programs). The asymptotic length $\left(\mathrm{L}_{\alpha}\right)$ was $56.7 \mathrm{~cm}, \mathrm{~K}$ was 0.29 year $^{-1}$ and the arbitrary origin of growth curve $\left(\mathrm{t}_{0}\right)$ was -0.66 year, hence von Bertalanffy growth equation was derived as $\mathrm{L}_{\mathrm{t}}=56.7\left(1-\mathrm{e}^{-0.29(\mathrm{t}-(-0.66)}\right)$ during 2009. The length at- age was estimated as $13.7 \mathrm{~cm}, 22.8 \mathrm{~cm}$, $33.8 \mathrm{~cm}, 41.1 \mathrm{~cm}, 44.4 \mathrm{~cm}, 48.61 \mathrm{~cm}, 52.9 \mathrm{~cm}, 54.1 \mathrm{~cm}$ and $56.7 \mathrm{~cm}$ in the I, II, III, IV, V, VI, VII, VIII and IX year respectively. The annual rate of natural mortality $(\mathrm{M})$ was found to be 0.66 , the fishing mortality (F) and total mortality $(\mathrm{Z})$ were 0.67 and 1.33 respectively. Exploitation ratio (E) was 0.50, whereas $\mathrm{E}$ max was found to be 0.48 , so the present study revealed that the fishing pressure was more than the optimum level on the stock of E. diacanthus. The mean length at first capture (Lc) was found to be 14 $\mathrm{cm}$ total length. The VPA analysis revealed that more fishing mortality was occurred in $16-17 \mathrm{~cm}$ size group and 36, $46 \mathrm{~cm}$ size groups. The recruitment of this species was peak in the month of July. Length weight relationship of this species was found to be $\mathrm{W}=0.002 \mathrm{~L}^{2.89}$ for pooled data. The relative condition factor $(\mathrm{Kn})$ and seasonal condition factor $(\mathrm{K})$ were varying among size groups, juvenile had highest $\mathrm{K}$ value.
\end{abstract}

Keywords: Epinephelus diacanthus, von Bertalanffy, ELEFAN I, relative condition factor

\section{Introduction}

The perches are one of the main constituents of the industrial and artisanal fisheries in tropical and temperate waters and usually have a high price in national and international markets. Perches are predominantly consisting of serranids (groupers), lutjanids (snappers) and Lethrinids (Emperors), the group perches offered enormous scope for augmented exploitation along the Indian coasts, whereas, George et al. (1977) ${ }^{[1]}$ estimated a potential yield of 2.5 lakh tonnes of perches from Indian waters. The average landing of perches in India was $3654.2 \mathrm{t}$. during the period $1985-89^{\text {[2] }}$, which was established a good fishery and thus the production increased many fold recently, during 2019 it was 2,97,103t. ${ }^{[3]}$. Groupers under the family serranidae are one of the most important resources in west coast of India, landed as by catch of trawlers and targeted catches of hand line, bottom set vertical line and traps, exploitation of these resources in the depth range of $30-150 \mathrm{~m}$ commercially in India ${ }^{[4]}$. Groupers are caught by both ecofriendly fishing fleet (with hand line and Bottom set line) and bottom trawlers in India, but the majority of the catch exploited by trawlers targeting juveniles less than 2 years age group from the shallow waters of $30-70 \mathrm{~m}$ contour of sandy/muddy grounds ${ }^{[4]}$. However, the annual landings of groupers in artisanal fishery in India from 2010 to 2019 fluctuated between a minimum of 3827 tonnes in 2011 and a maximum 51433t during 2019 which
Corresponding Author:

Fishery Survey of India,

Kochangadi, P.B.No.853, Kochi,

Kerala, India 
contributed $1.4 \%$ of total fish landing in India ${ }^{[3]}$. Among all the groupers exploited in the west coast, the spinycheek grouper (E. diacanthus) is the largest resource contributed in the perch fishery of southwest coast of India, however $E$. diacanthus is listed as near threatened in IUCN Red List ${ }^{[5]} . E$. diacanthus distributed in the continental shelf of the northwestern Indian Ocean from the Gulf of Aden to Sri Lanka and Madras (questionable), however it is not available in the Persian Gulf or the Red Sea ${ }^{[7]}$, and also in the eastern Indian Ocean off Thailand ${ }^{[8,9]}$ and Hong Kong ${ }^{[10]}$. Literature so far available on this resource in India is inadequate particularly on its distribution pattern ${ }^{[11]}$ and biology ${ }^{[12]}$, mostly dealing on catch statistics ${ }^{[13,14]}$ population dynamics $[15,16,17,18,19,20$, ${ }^{14,21,22]}$ of $E$. diacanthus in Indian waters based on fisheries dependent data. However, few studies on age and growth based on fishery independent data in Oman waters of Arabian Sea ${ }^{[23,24]}$ also available. There is no published information on the distribution of E. diacanthus is available in Indian coast, hence this is the first authentic information based on sea truth data on distribution pattern of this species, population dynamics and length weight relationship. The main objectives of the studies are analyzing distribution pattern and estimation of parameters such as asymptotic length $\left(\mathrm{L}_{\alpha}\right)$ growth coefficient $(\mathrm{K})$ natural mortality $(\mathrm{M})$ fishing mortality (total mortality $(\mathrm{Z})$, exploitation rate $(\mathrm{E})$, recruitment pattern Lc / $\mathrm{L} \alpha$ and $\mathrm{M} / \mathrm{K}$ (where Lc is length at first capture) and other scientific management parameters such as length weight and condition factor $(\mathrm{Kn})$ of $E$. diacanthus from southwest coast of India for the better management strategies.

\section{Materials and Methods}

Monthly samples of E. diacanthus were collected during 2008 to 2010 from the southwest coast of India, within the depth range of 30-110 m were analysed and 2017 data also included for studying distribution. The area between Lat. $7^{\circ} \mathrm{N}$ and $10^{\circ} \mathrm{N}$ were sampled. Samples were collected by vessel M.F.V.Matsya varshini belongs to Fishery Survey of India, using expo model $(45.6 \mathrm{~m}$ ) bottom trawl (mesh size $30 \mathrm{~mm}$ in code end) in the depth between 30-60m and Matsya Sugundhi envisaged for the operation of fish trap and line (hand/ machine reel) fishing between the depth 60 and $110 \mathrm{~m}$. These traps were with diameter of $2 \mathrm{~m} \times 1 \mathrm{~m} \times 1 \mathrm{~m}$ with a funnel shaped webbings ( $\varnothing 1.5 \mathrm{~mm}$ HDPE of $100 \mathrm{~mm}$ dia.) channel as entrance with single side opening. The frame of the trap was made by $\varnothing 12.5 \mathrm{~mm}$ mild steel rod, the trap was covered by $\varnothing$ $3.0 \mathrm{~mm}$ thickness HDPE webbings with mesh size of $100 \mathrm{~mm}$ and the hand line fishing (Machine reel contains 5 hooks (fishing hook size -No.5) for each line) in the un-trawlable areas between $60-100 \mathrm{~m}$ depth. Total length and weight were measured to the nearest $1 \mathrm{~mm}$ and $0.5 \mathrm{~g}$ accuracy respectively. There are about 1852 specimens were included for this study to establish length frequency analysis. Population parameters were estimated by length frequency based computer program ELEFAN I as explained by Pauly and David (1981) ${ }^{[25]}$ and Saeger and Gayanilo (1986) ${ }^{[26]}$. ELEFAN I was used to eastimate the growth parameters as $\mathrm{L}_{\alpha}$ and $\mathrm{K}$ of the von Bertalanffy growth equation, for this purpose length frequency data during 2008-2009 were utilized. The growth performance of $E$. diacanthus population in terms of length and growth compared using the following index.

$\varnothing=\log \mathrm{K}+2 \log \mathrm{L}_{\alpha}{ }^{[27]}$.

The parameter $\mathrm{M}$ was estimated using the empirical relationship of Pauly (1980) ${ }^{[28]}$.

$\log _{10} \mathrm{M}=-0.0066-0.279 \log _{10} \mathrm{~L}_{\alpha}+0.6543 \log _{10} \mathrm{~K}+$
$0.4634 \log _{10} \mathrm{~T}$

Where $\mathrm{L}_{\alpha}$ is expressed in $\mathrm{cm}$ and $\mathrm{T}\left(28^{\circ}\right)$ is the mean annual environmental temperature.

The total mortality was estimated from catch curve based on the following equation,

$\mathrm{Z}=\mathrm{K}\left(\mathrm{L}_{\alpha^{-}} \mathrm{L}^{-}\right) / \mathrm{L}^{-}-\mathrm{L}^{\prime}$

Where the $\mathrm{L}^{-}$is the mean length in the sample, computed from $\mathrm{L}$ ' upward and $\mathrm{L}$ is the lower limit of the smallest length class used in the computation of $\mathrm{L}^{-}{ }^{[29]}$. Fishing mortality $(\mathrm{F})$ was estimated by substracting $\mathrm{M}$ from $\mathrm{Z}$, the exploitation rate (E) was computed from the following expression $E=F / Z$ [30] (Gulland 1971). Relative yield per recruit $\left(\mathrm{YR}^{-1}\right)$ was obtained from estimated growth parameter and probability of capture by length. Exploitation rates at $50 \%$ of the biomass $\left(\mathrm{E}_{50}\right)$ and maximum yield per recruit $\left(E_{\max }\right)$ were calculated from relative yield per recruit $(\mathrm{Y} / \mathrm{R})$ and relative biomass per recruit (B/R) using knife-edge selection [31]. All the other calculations were carried out using the complete ELEFAN program package developed by ICLARM ${ }^{[32]}$.

The $t_{0}$ was estimated by the following method of von Bertalanffy (1934) and Vivekanandan (2005) ${ }^{[33]}$ as follows, $\mathrm{Ln}\left(1-\mathrm{L}(\mathrm{t}) / \mathrm{L}_{\alpha}\right)=-\mathrm{K}^{*} \mathrm{t}_{0}+\mathrm{K} * \mathrm{t}$, the age $\mathrm{t}$ was regressed against $-\mathrm{LN}\left(1-\mathrm{L}(\mathrm{t}) / \mathrm{L}_{\alpha}\right)$. The slope $\mathrm{b}$ in the regression $=\mathrm{K}$ and intercept $\mathrm{a}=-\mathrm{K} * \mathrm{t}_{0}$, so, the annual $\mathrm{t}_{0}=-\mathrm{a} / \mathrm{b}$

Length weight relationship was calculated by least square method using the formula of $\mathrm{W}=\mathrm{a} \mathrm{L}^{\mathrm{b}}$ and its logarithmic form $\log \mathrm{W}=\log \mathrm{a}+\mathrm{b} \log \mathrm{L}$. As $E$ diacanthus is a protogynous hermaphrodite, differentiation of sex in certain age group is difficult, so distinguishable female and remaining pooled data were analysed for this study. The seasonal condition factor $(\mathrm{K})$ was estimated following the standard formula $(\mathrm{K}=\mathrm{w} / \mathrm{L} 3$ $* 100)^{[34]}$, the relative condition factor $\mathrm{K}_{\mathrm{n}}$ was calculated by the following equation, $\mathrm{K}_{\mathrm{n}}=\mathrm{W} / \mathrm{W}$ (where $\mathrm{W}=$ estimated weight and $\mathrm{w}=$ calculated weight $)^{[35]}$.

\section{Results and Discussion}

\subsection{Demographics of $E$. diacanthus}

\subsubsection{A glimpse on Distribution}

The present study analysed past 20 years (2000-2019) survey data in west coast, Wadge Bank and Gulf of Mannar revealed that the distribution of $E$. diacanthus restricted up to certain latitude $\left(8^{\circ} \mathrm{N}\right)$ of southwest coast of India, no specimen beyond further south in Wadge bank and Gulf of Mannar was reported during the study period, which was corroborated with the recent studies ${ }^{[11]}$. The juveniles of less than 1year age group and maturing stages of less than 3 years age group of $E$. diacanthus occupies predominantly in the shallow muddy habitat $(30-50 \mathrm{~m})$ in the area between Lat. $9^{\circ} \mathrm{N}$ and $11^{\circ} \mathrm{N}$, whereas, this age groups also sporadically sharing the niche of adults in the neighbor rocky grounds of $60-110 \mathrm{~m}$. However, the larger specimens of more than 3 years age groups occupies exclusively the rocky habitat of the depth between $60-110 \mathrm{~m}$ between the area Lat. $9^{\circ}$ and $11^{\circ} \mathrm{N}$. Occasionally few records on the occurrence of $E$. diacanthus were observed from the depth of 180-230m along with other deep sea fishes during the year 2017 in the area between $10^{\circ} 07^{\prime} \mathrm{N} 75^{\circ} 39^{\prime} \mathrm{E}$ and $10^{\circ} 04^{\prime} \mathrm{N} 75^{\circ} 38^{\prime} \mathrm{E}$. Moreover, the larger size above $35 \mathrm{~cm}$ total length of 3 years age group was not recorded from shallow muddy grounds between the area Lat. $9^{\circ}$ and $11^{\circ} \mathrm{N}$ during the past 20 years survey is imperative. Silas (1969) ${ }^{[36]}$ also collected juveniles of this species in west coast of India from $30-60 \mathrm{~m}$ and adults in 100-160 m depths 
of west coast [37]. During the regular demersal fishery resources survey 3 specimens of $E$. diacanthus of $21-26 \mathrm{~cm}$ TL was collected from 180-230m depth, which was the maximum depth of occurrence of this species reported so far in Indian waters. It is worth to mention here that, $E$. diacanthus was collected from this depth (180-230m) along with Epinephelus episticus, Neoharriotta pinnata (Juveniles of $38-76 \mathrm{~cm}$ TL), Houndshark, Tetronarce macneilli, Hyporthodus octofasciatus, Lipocheilus carnolabrum, Hypopleuron caninum, deep sea gobiidae. However, Studies by Joseph et al. (1987) ${ }^{[38]}$ revealed that E. diacanthus was one of the dominant species of groupers, and which were most abundant in the $20-50 \mathrm{~m}$ depth zone in west coast of India, their abundance decreasing with depth, as also described that, there was no catch of these fishes in the 200$500 \mathrm{~m}$ depth zone. De Bruin et al. (1995) ${ }^{[39]}$ stated that this species forms large schools on Pakistan muddy trawling grounds at depths of 2 to $50 \mathrm{~m}$. Abdessalaam (1995) [40] reported that $E$. diacanthus occurs in Omani waters up to 110 $\mathrm{m}$ depth. In addition, $E$. diacanthus recorded by an underwater visual census on a hard coral and hard bottom in shallow water $(2-12 \mathrm{~m})$ which may be juvenile habitat [11], extends information about distribution of this species, was reported up to $160 \mathrm{~m}$ in India ${ }^{[36]}$.

\subsubsection{Age and growth}

Restructured length frequency distributions of E. diacanthus are shown in Fig.I. Growth parameters of von Bertalanffy growth equation for $E$. diacanthus was estimated as asymptotic length $\left(\mathrm{L}_{\alpha}\right)=56.7 \mathrm{~cm}$ and $\mathrm{K}=0.29$ year $^{-1}$ and the arbitrary origin of growth curve $\left(\mathrm{t}_{0}\right)$ was -0.66 year $\left(\mathrm{L}_{\mathrm{t}}=56.7\right.$ $\left(1-\mathrm{e}^{-0.29}(\mathrm{t}-(-0.66))\right.$. The growth performance index was estimated as 2.96 for this model. Stock rebuilding is expected to be slow, as the species had low annual growth coefficient and also had a low natural mortality rate, the present species (E. diacanthus) is relatively slower in growing nature compared to its congener E. bleekeri and E. malabaricus ${ }^{[41]}$. According to Spare and Vinema (1992) ${ }^{[42]}$ the fishes with lower $\mathrm{K}$ values are characteristic with lower natural mortality, whereas it is related to age and size of the fish. $\mathrm{K}$ values in the present study is 0.29 year $^{-1}$ and its corresponding $M$ value is 0.66 therefore, the $\mathrm{M} / \mathrm{K}$ ratio of $E$. diacanthus is 2.27 . Moreover, the $\mathrm{M} / \mathrm{K}$ ratio in fishes generally falls within the limit of $1.5-2.5$, as reported for several other tropical fishes $[43,44]$ and in the present study, $\mathrm{M} / \mathrm{K}$ ratio falls with in this limit. However, the $\mathrm{M} / \mathrm{K}$ ratio is found to be constant among the closely related species ${ }^{[45]}$. The $\mathrm{L}_{\max } / \mathrm{L}_{\alpha}$ ratio was 0.95 , which was within the recommended range ${ }^{[31]}$. The length atage was estimated using von Bertallanfy growth equation as $13.7 \mathrm{~cm}, 22.8 \mathrm{~cm}, 33.8 \mathrm{~cm}, 41.1 \mathrm{~cm}, 44.4 \mathrm{~cm}, 48.61 \mathrm{~cm}$, $52.9 \mathrm{~cm}, 54.1 \mathrm{~cm}$ and $56.7 \mathrm{~cm}$ in the I, II, III, IV, V, VI, VII, VIII and IX years respectively (Fig. 2). However, Manojkumar (2005) ${ }^{[14]}$ estimated five age groups with higher annual growth coefficient $(\mathrm{K})$ value of $0.65 \mathrm{yr}^{-1}$. studies on age and growth of $E$. diacanthus from Arabian sea revealed that the asymptotic length varied between $49 \mathrm{~cm}^{[18]}$ to $61 \mathrm{~cm}$ ${ }^{[23]}$ and the annual growth coefficient varied between $0.21 \mathrm{yr}^{-1}$ [46] to $0.65 / \mathrm{yr}^{[14]}$. The estimation of longevity $\left(\mathrm{T}_{\max }\right)$ of $E$. diacanthus was nine years in the present study, which was corroborated with the studies of Mehanna et al. (2013) [23] (who done back calculation from otolith annual rings) and Edwards and Shaher, (1991) ${ }^{[46]}$ from Oman and Yemen respectively, however, Chakraborty, $1994{ }^{[16]}$ reported 5 years of $t_{\max }$ in west coast of India. Moreover, few of the studies are done based on the fishery independent data as if in the present report, remaining studies $[16,18,20,14]$ the data have been done by the fishery dependent data collected form commercial landings centers with limitations in size selection by the commercial trawlers and artisanal hook and line fishing fleets.

\subsubsection{Mortality rates and Yield per recruit and biomass per recruit}

The estimation of total mortality $(\mathrm{Z})$ was made using length converted catch curve method, darkened quadrilateral represents the points used in estimating $\mathrm{Z}$ through least square linear regression. The fishing mortality $(F)$ was taken by substraction of $\mathrm{M}$ from $\mathrm{Z}$ and it was found to be 0.67 whereas $M$ was 0.66 and $Z$ was 1.33. Exploitation ratio (E) was estimated using the formula $\mathrm{E}=\mathrm{F} / \mathrm{Z}^{[30]}$ and it was 0.50 . It is suggested that the stock of $E$. diacanthus in southwest coast reached the optimum fishing pressure, as far as this stock is concerned, if the fishing pressure is augmented from the present level may cause overfishing, which also lead to further decline of the fish stock in southwest coast of India. This assumption was made based on the statement of Gulland (1971) ${ }^{[30]}$ who stated that when $\mathrm{E}$ is more than 0.5 , the stock is generally supposed to be over fishing. The fishing mortality also seem to be of great concern $(\mathrm{F}=0.67)$, general assumption that sustainable yield is optimized when $\mathrm{F} \approx \mathrm{M}$ ${ }^{[30]}$. However, the relative yield per recruit and biomass per recruit (Fig.3) were determined as a function of $\mathrm{Lc} / \mathrm{L}_{\alpha}(0.24)$ and $M / K$ (2.27), which shows that the present exploitation rate $(\mathrm{E}=0.50)$ has exceeded the optimum exploitation rate $\left(E_{\max }=0.48\right)$. As the present exploitation rate is $4.16 \%$ higher than the $E_{\max }$, hence it could be stated that this fishery is under over fishing. The results of the present study will be an accentuate to find out suitable measure for sustainable fishery management of spinycheek grouper, Epinephelus diacanthus in southwest coast of India.

\subsubsection{Selection pattern and recruitment pattern}

The length at first capture $\left(\mathrm{L}_{\mathrm{c}}\right)$ for selection pattern (Fig. 4) was $14.0 \mathrm{~cm}$ on the basis of present net, for this study catches from the trawl survey only taken, hence, this is likely to be changed in case of commercial trawler, who are having different mesh size in the code end and sometimes the commercial landings data may oversight by source of catch (i.e. along with trawl net, catch may be brought to the landing centers by hook and line or trap fishing with various mesh size on trap cover and hook size). However, Manojkumar (2005) ${ }^{[14]}$ and Chakraborty (1994) ${ }^{[16]}$ have reported the Lc value of $11 \mathrm{~cm}$ and $16.7 \mathrm{~cm}$ from commercial landings of Malabar coast and Bombay waters respectively. However, Mehanna et al. (2013) ${ }^{[23]}$ reported the length at first capture at $21.8 \mathrm{~cm}$ TL from Omen water based on fishery independent survey data. The virtual population analysis (VPA) revealed that all the age groups of $E$. diacanthus are vulnerable to these fishing gears such as bottom trawl in shallow waters up to $60 \mathrm{~m}$ depth as by catch species and by bottom set line fishing as targeting species from $60-100 \mathrm{~m}$ depth contour of southwest coat of India. However, $16-17 \mathrm{~cm}$ size groups are more vulnerable to this fishing gear, which had more fishing mortality according to VPA analysis, followed by $36 \mathrm{~cm}$ and $46 \mathrm{~cm}$ length groups (Fig.5).

The recruitment pattern estimated by the separation of the normal distribution of the peaks by means of the NORMSEP program. It was observed that $E$. diacanthus was recruited in to the fishery during June -August and the Peaks appeared in 
July (Fig. 6). On the review recruitment pattern of $E$. diacanthus in pertinent literature, it was observed that its recruitment occurs between May to September in west coast of India ${ }^{[14]}$ in August-October in Omen waters of Arabian Sea ${ }^{[24]}$.

\subsubsection{Length weight relationship}

The total length varied between $4-54 \mathrm{~cm}$, the body weight varied between 3.5-2900 g. The length weight relationship of Epinephelus diacanthus is described by the following equation for distinguishable female it was $\log \mathrm{w}=-1.619+$ $2.83 \log \mathrm{L}(\mathrm{r}=0.958)$ and pooled data $\log \mathrm{w}=-1.628$ $+2.8208 \log \mathrm{L}(\mathrm{r}=0.969)$ and its exponential forms are $\mathrm{W}=$ $0.0238 \mathrm{~L}{ }^{2.8322}$ and $\mathrm{W}=0.002 \mathrm{~L}{ }^{2.89}$ respectively. The unchanging body form and specific gravity of a fish are supposed to yield a regression coefficient (b) value of 3 , where fish exhibits isometric growth. The pooled ' $b$ ' value of $E$. diacanthus was subjected to $t$ test and the test revealed that this species exhibits isometric growth since its $b$ value did not significantly $(\mathrm{P}>0.05)$ differ from theoretical value of 3 . According to pertinent literature the ' $b$ ' value of $E$. diacanthus varying between $2.51^{[47]}-3.01^{[24]}$ in the Arabian Sea (table.1).

The size wise relative condition factor $(\mathrm{Kn})$ values were more than 1.00 in the lower size groups ranged between 4 and $8 \mathrm{~cm}$ (Fig. 7) whereas, and the Kn was found to be around or less than 1.00 in the $12 \mathrm{~cm}$ and above size groups, however the mean $\mathrm{Kn}$ values beyond $12 \mathrm{~cm}$ were not significantly differed (t-0.06; P>0.05) which indicates that smaller specimens of $E$. diacanthus were more healthy and robust than the elder ones, similar observations were reported in other teleosts ${ }^{[49,50]}$. In some species higher condition factor $(\mathrm{Kn})$ was reported in larger animals than the smaller size groups ${ }^{[6,48,42]}$. Numerous studies have been conducted on seasonal condition factor (K) cycle in teleost, since the difference in values of condition can often yield perception on the environments of the fish's mainly dealt with timing and duration of breeding cycle, food supply, well-being etc., ${ }^{[6,43]}$.

Seasonal variation of condition factors: The values of these factors to fishery management is, therefore imperative and the purpose of tracing the $\mathrm{K}$ cycle of $E$. diacanthus a commercially important species, to find out its relationship with the growth and the breeding and feeding cycles, the monthly condition of the fish for one year 2008-2009 and the change in condition with the growth of the fish were worked out. As the seasonal condition factor $(\mathrm{K})$ directly reflects breeding cycle and feeding ${ }^{[6]}$ seasonal variation of condition factors $(\mathrm{K})$ of $E$. diacanthus revealed a lower value during May and June in connection to occurrence of more mature specimens in these months, Qasim, $1957^{[51]}$ suggested that the hiking and waning of the condition factor could be probably due to the building up or loss of reserves of the fish. The $\mathrm{K}$ showed lower value during peak spawning period (May-June) and an increasing trend during August and September (Fig. 8), which specified that the $\mathrm{K}$ is directly following the energy transfer for gonadal recrudescence and gametogenisis [52]. Similarly, Nair et al. (1983) [6] also reported inverse relation between seasonal condition factor (K) and GSI during spawning period in perchlet. Moreover, Hickling (1945) ${ }^{[53]}$ found low and high value of K before and after spawning, which was further explained by him as due to availability and intake of food during post spawning. However, analyzing the data on distinguished females of various size group revealed that the specimens attain below length at first maturity $(20 \mathrm{~cm})$ are robust in nature and had higher K value (Fig. 9). Similarly, Abdulaziz et al. (2015) ${ }^{[24]}$ reported higher $\mathrm{K}$ value in $E$. diacanthus during prespawning period in Omen waters. Generally, the condition factors are negatively correlated to degree of ripening / spawning cycle $[54,43]$.

Table 1: Comparison studies on Length weight relationship of E. diacanthus with pertinent literatures (Pooled data only considered)

\begin{tabular}{|c|c|c|c|c|c|c|}
\hline \multirow{2}{*}{ SI. No. } & \multicolumn{2}{|c|}{ Length (cm) } & \multicolumn{2}{c|}{ Weight (g) } & \multirow{2}{*}{ Slope ('b' value) } & \multirow{2}{*}{ Sources } \\
\cline { 2 - 5 } & min. & max. & min. & Max. & & Abdurahiman et al. 2004 \\
\hline 1 & 14.7 & 38.7 & 156.0 & 720.0 & 2.51 & Abdulaziz et al. 2015 \\
\hline 2 & 6.7 & 58.1 & 4 & 2575 & 3.08 & Edwards \& Shaher. (1991) \\
\hline 3 & & 52.7 & & & 2.94 & Manojkumar 2005 \\
\hline 4 & 14 & 47.2 & 40 & 1050 & 2.82 & McIlwain et al. 2006 \\
\hline 5 & 26 & 53 & 310 & 2280 & 2.93 & Ranjeet et al. 2015 \\
\hline 6 & 4 & 28 & & 504 & 2.53 & Present study \\
\hline 7 & 4 & 54 & 3 & 2900 & 2.89 & \\
\hline
\end{tabular}

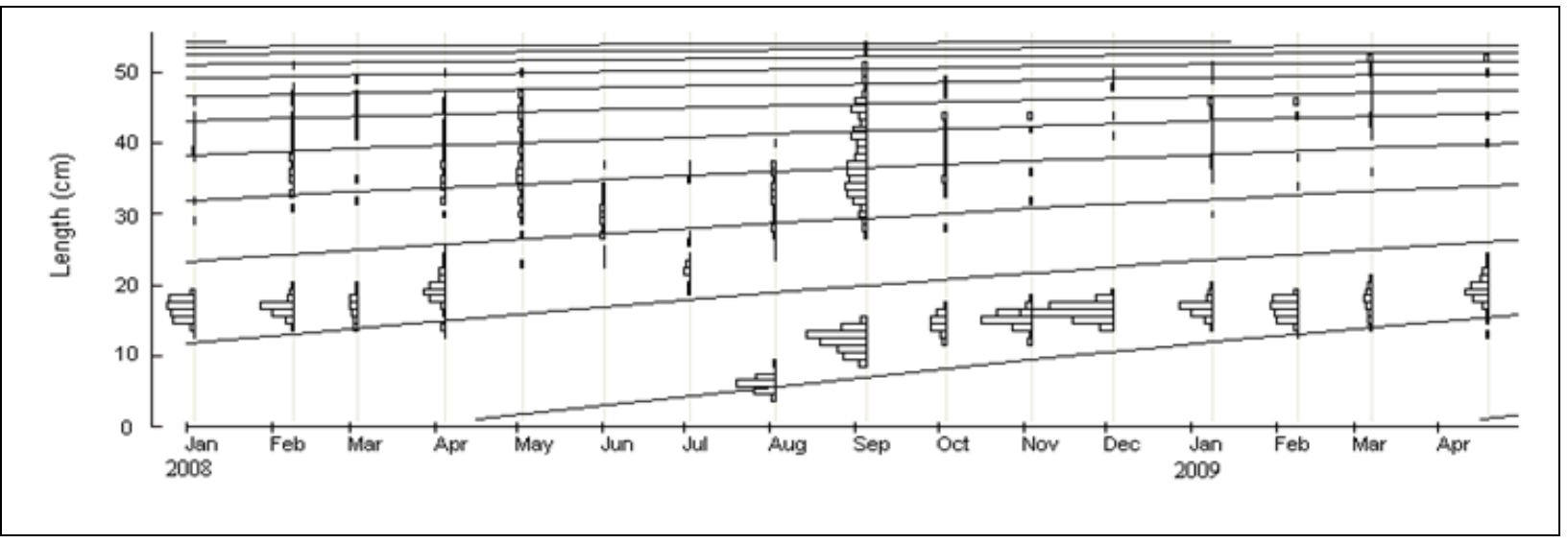




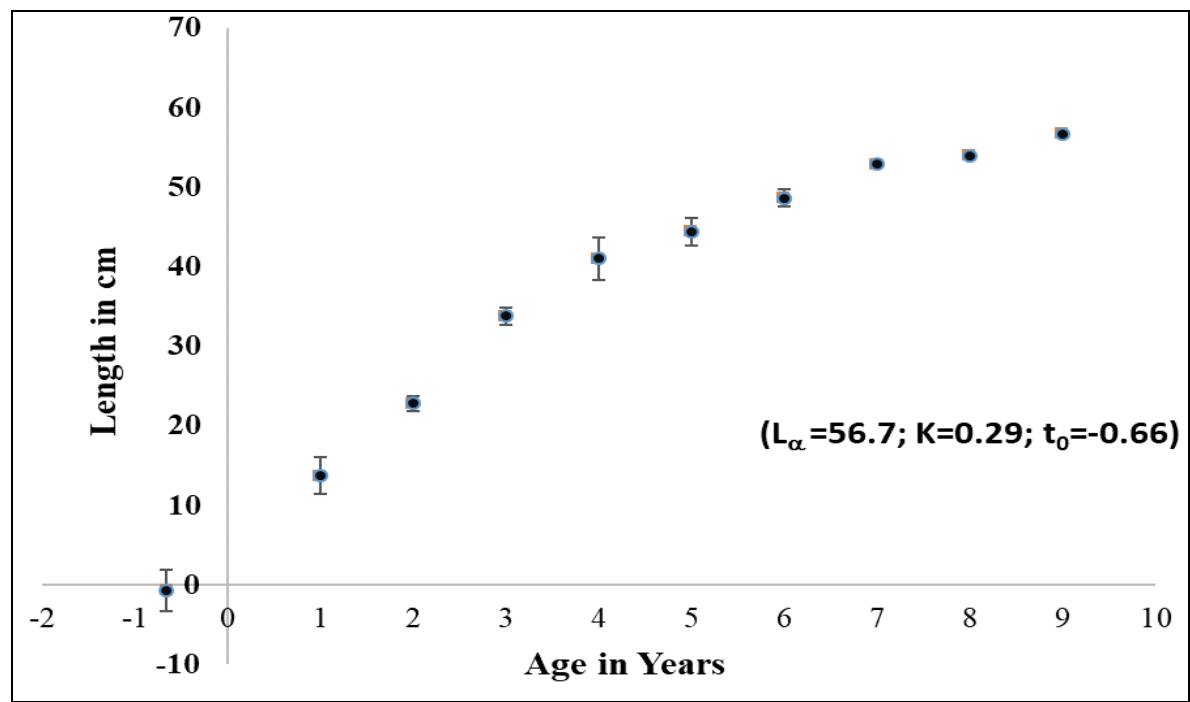

Fig 2: Length at age estimated from the length frequency using von Bertalanffy plot

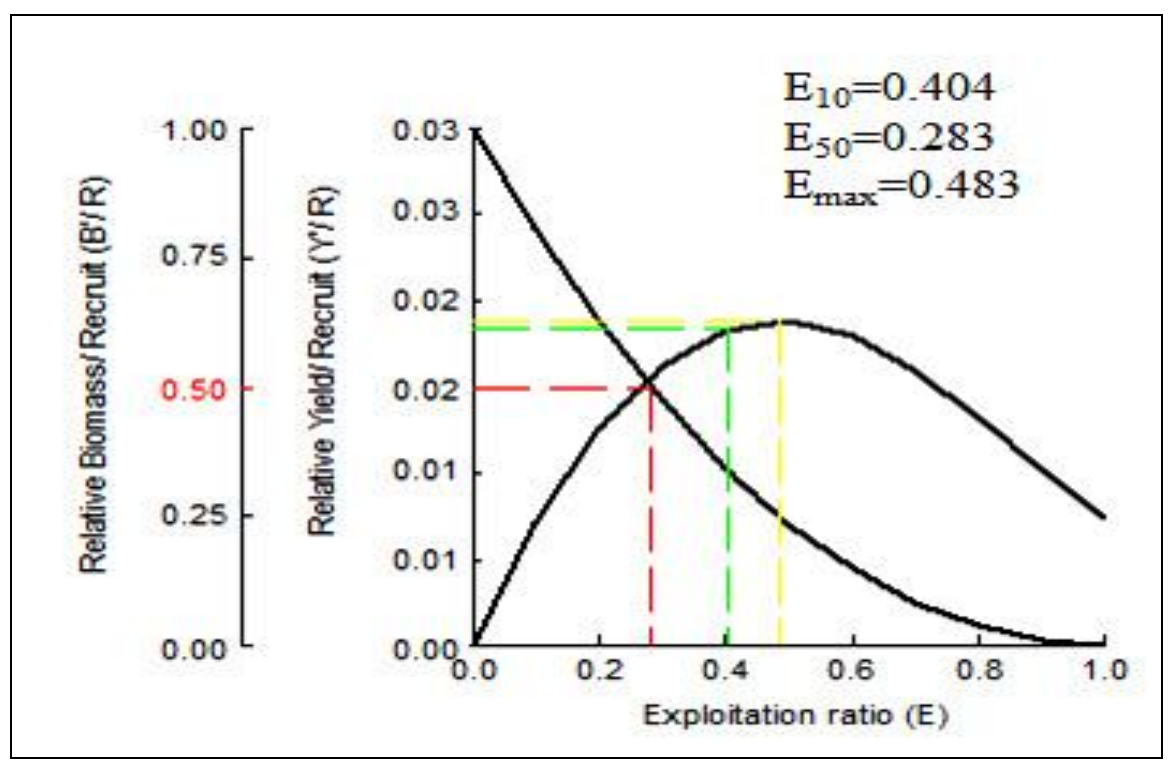

Fig 3: Relative yield per recruit analysis using Beverten and Holt (Knife -edge selection) model for estimation of stock status of E. diacanthus from south west coast of India

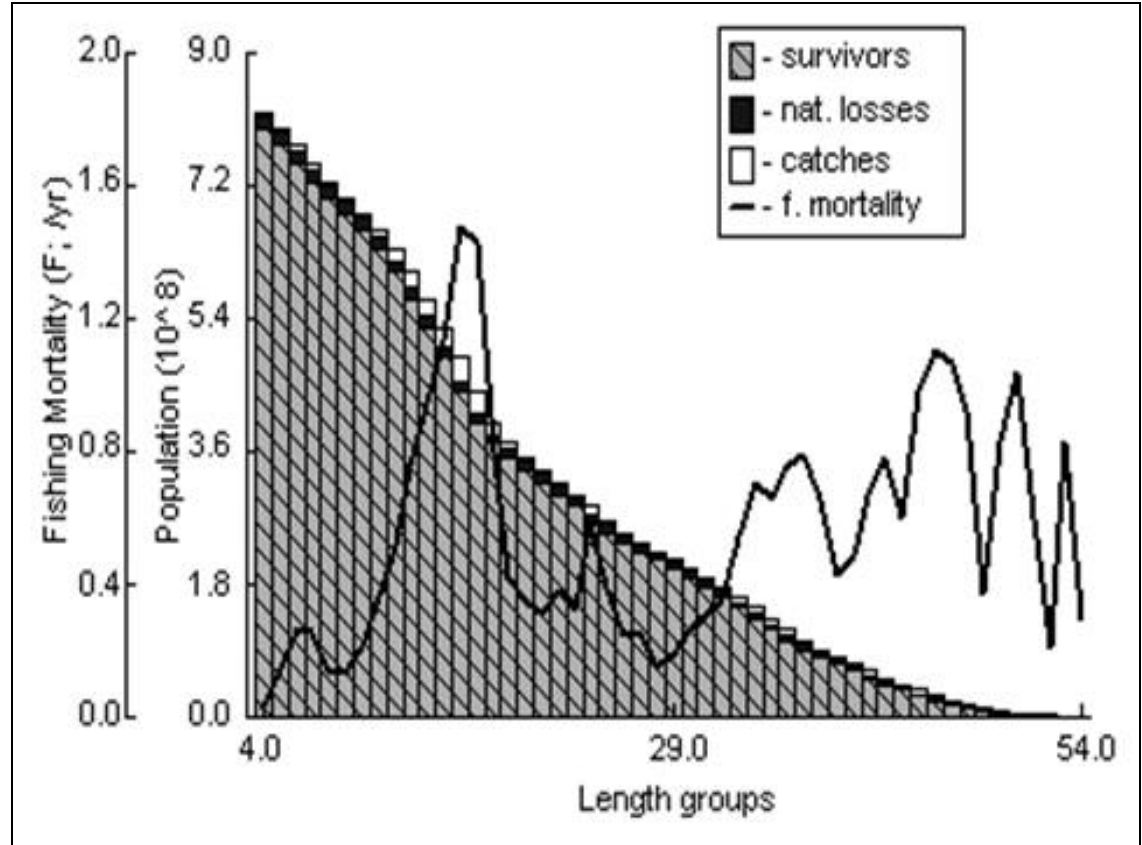

Fig 4: Length structured Virtual Population Aanalysis of E. diacanthus from southwest coast of India peak fishing mortality at 16-17cm TL. 


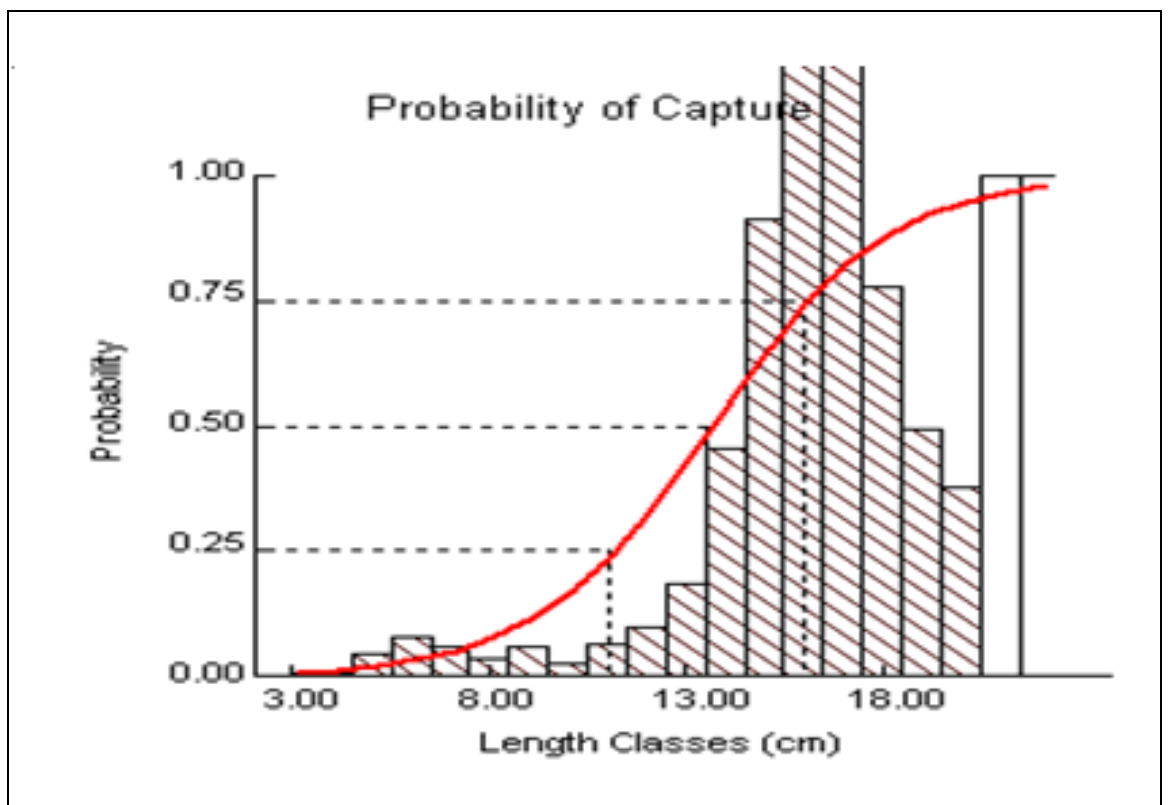

Fig 5: Probability of length at capture of $E$. diacanthus from South west coast of India, $\mathrm{L}_{50}=14.0 \mathrm{~cm}, \mathrm{~L}_{75}=16.0 \mathrm{~cm}$ based on catches of bottom trawl survey with $30 \mathrm{~mm}$ code end mesh.

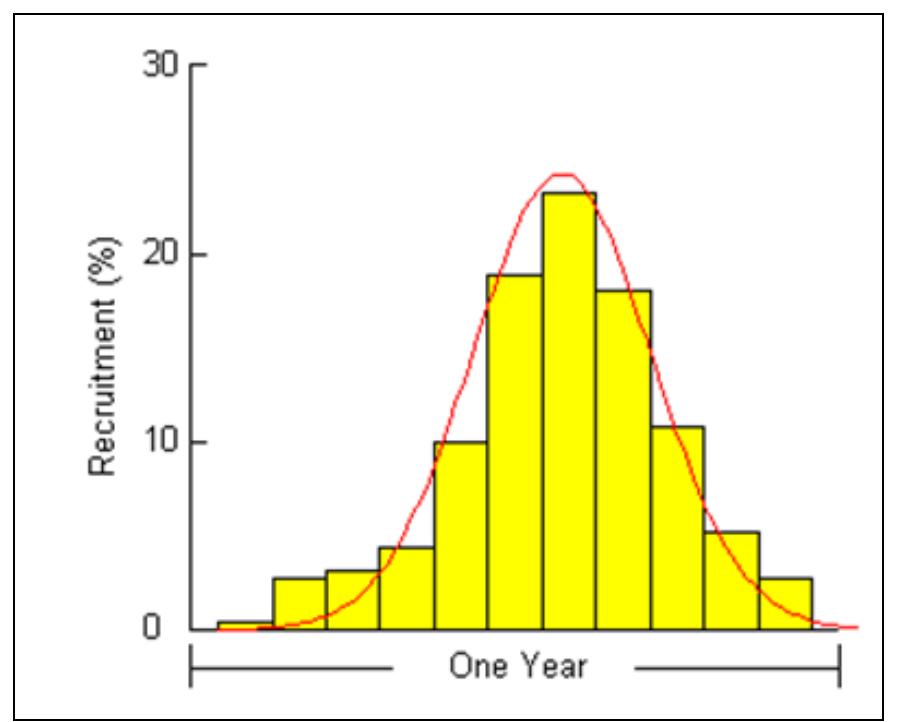

Fig 6: Recruitment pattern computed for E. diacanthus from southwest coast of India for the period of one year from January to December.

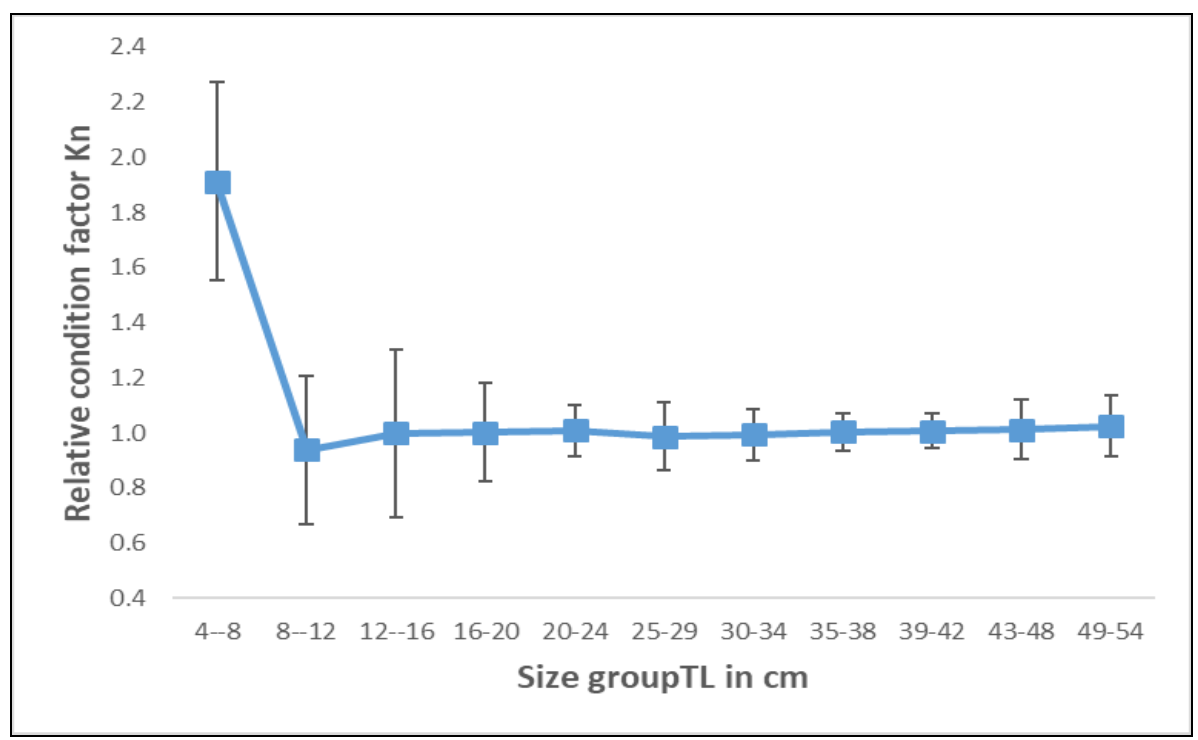

Fig 7: Size wise relative condition factor $(\mathrm{Kn})$ of E. diacanthus including immature, distinguished female and transitional stage specimens from south west coast of India. 


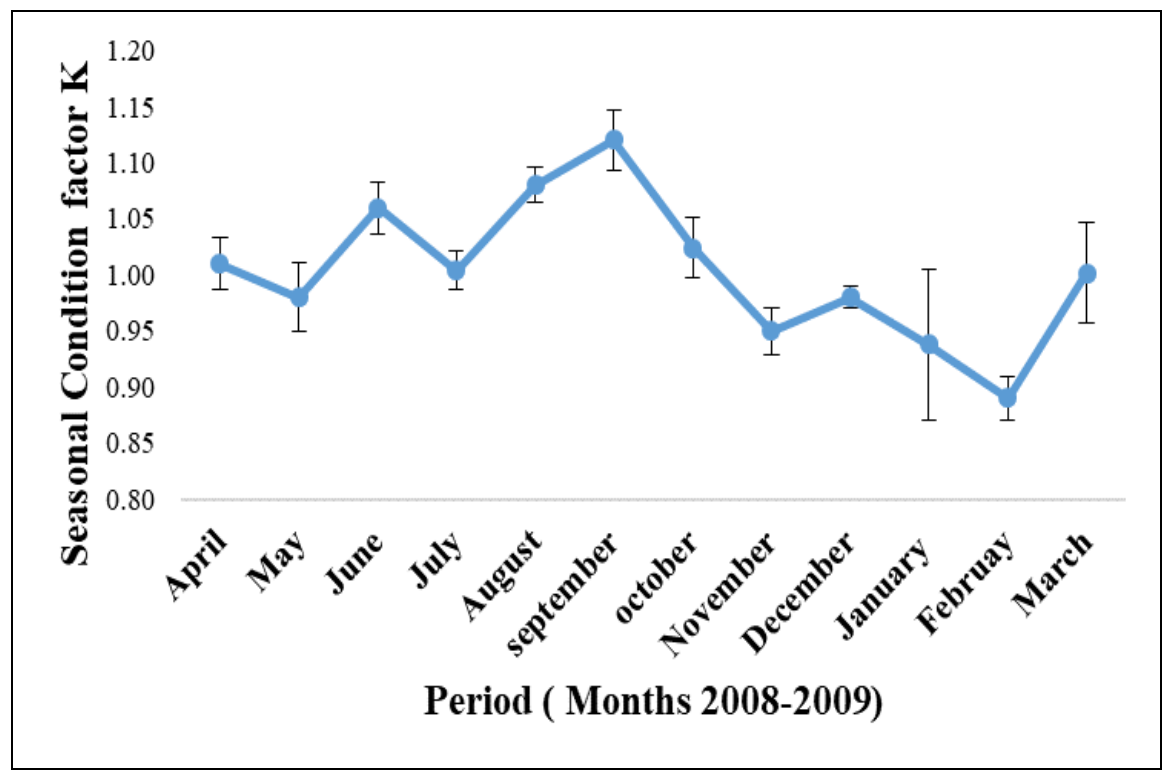

Fig 8: temporal changes of seasonal condition factor $(\mathrm{K})$ of $E$. diacanthus including immature, distinguished female and transitional stage specimens from south west coast of India

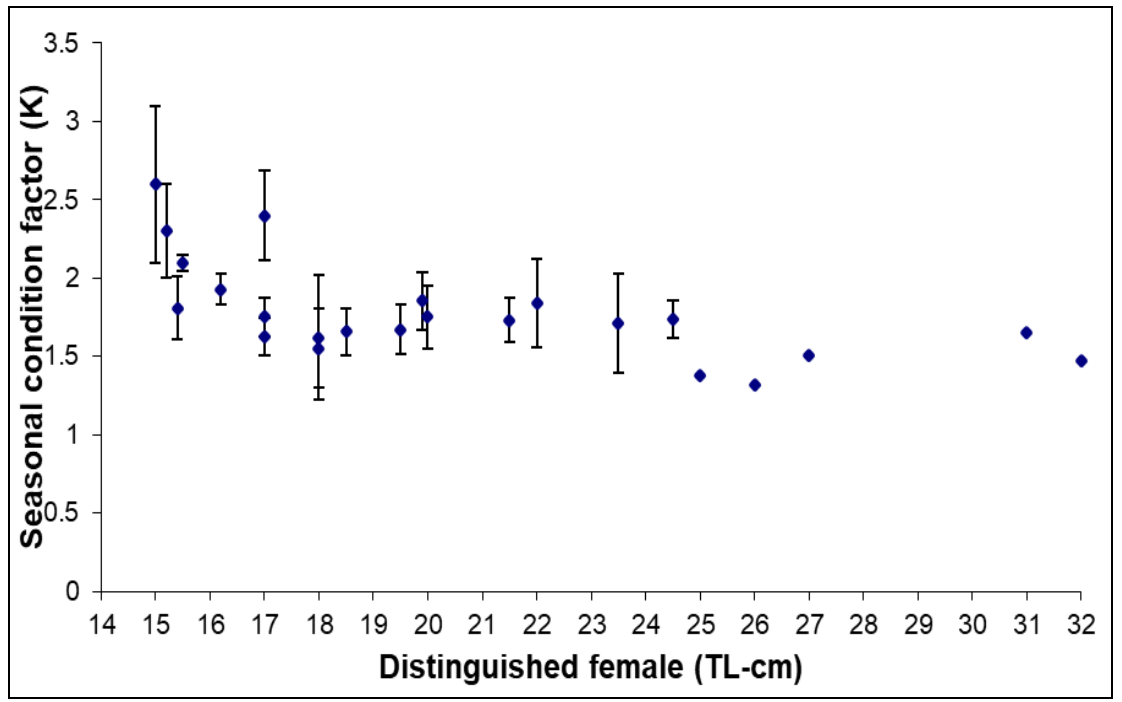

Fig 9: Size wise seasonal condition factor $(\mathrm{K})$ of distinguished female specimens of $E$. diacanthus (above $25 \mathrm{~cm}$ TL very few distinguished female specimens were observed, remaining are in transitional stage, which are not included in this graph)

\section{Conclusion}

The pertinent literatures from southwest coast of India are the studies based on fishery dependent data which has a bottleneck in obtaining data during trawl ban i.e during the period between June and July. The present study has continuous fishery independent data which anticipated to compromise the omissions in the existing studies from the west coast of India on E. diacanthus. There were two age groups taken by our survey from the fishery, exclusively by two different types of fishing fleet, the smaller age group mostly taken by trawl catches and larger size of more than 3 years' age group were explored by bottom set line, hand line and trap fishing of two different niche. The results of the study have expanded knowledge on stock and distribution of the spinycheek grouper in the west coast of India. Our trawl survey and Trap survey finding from depth of 30-60 m and $60-110 \mathrm{~m}$ respectively from the Lat. $9^{\circ} \mathrm{N}$ to $11^{\circ} \mathrm{N}$ revealed a clear depth dependent distribution pattern with age of the fish is established, however, south of the Lat. $8^{\circ} 30^{\prime} \mathrm{N}$ to Gulf of Mannar no specimen of $E$. diacanthus was recorded. The values of regression coefficients in length-weight relationships of $E$. diacanthus in different studies exhibit high variations that may be explained by differences in ecological condition of the habitats. The size group of $16 \mathrm{~cm}$ TL were under more fishing pressure, however its larger than the length at first capture $(14 \mathrm{~cm})$ from the fishery and it was less than the length at first maturity is viewed a serious threat for the fishery. The exploitation rate of $E$. diacanthus in the southwest coast of India are slightly (4.14\%) higher than the predicted $\mathrm{E}_{\max }$ an indicator of overfishing of this species in this coast. Moreover, substantial quantity of the catch contained juveniles, give alarm to minimize the fishing efforts and also to encourage ecofriendly fishing techniques in the rocky grounds in a sustainable mode for the conservation of this resource. However, the present study shows peak recruitment of $E$. diacanthus was during July and the present trawl ban in west coast of India implemented by Government of India has also been fit during this period for the conservation and sustainable fishery.

\section{Acknowledgement}

We thank the Director General, Fishery Survey of India, for providing facilities to conduct the studies. We thank Dr. E. Vivekanandan, Principal Scientist (Retd.), CMFRI, Chennai, 
for his valuable suggestions and encouragement during the study, we also thank Dr. K.P. Philip Zonal Director (Retd.) and Mr. V. Sivaji Senior Fisheries scientist (Retd.) for their valuable advices and support during the study.

\section{References}

1. George PC, Antony Raja BT, George KC. Fishery resources of the Indian Economic Zone. Seminar International Fisheries Project Silver Jubilee, 1977, 70120.

2. James PSBR, Lazarus S, Armugam G. Present status of major perch fisheries in India. In K. Rengarajan and P. Sam Bennet (eds) Bulletin of Central Marine Fisheries Research Institute. 1994; 47:1-9.

3. CMFRI. Central Marine Fisheries Research Institute Annual Report. Technical Report. CMFRI, Kochi, 201819.

4. Ramachandran S. Prospects of sustainable exploitation of Demersal Fishery resources in Indian EEZ. 2015. In. Proceedings of national workshop on Lesser Known Marine Animals of India at Zoological Survey of India. 2015, 34:523-535.

5. Sadovy Y, Pollard D, Russell B, Heemstra PC. Epinephelus diacanthus. In: IUCN 2011. IUCN Red List of Threatened Species. 2008, Version, 2011. 2. <www.iucnredlist.org>.

6. Nair JR, Nair NB, Balasubramanian NK. Condition and relative condition cycles in the tropical glassy perchlet Chanda (=Ambassis) commersonii (Cuv. and Val.) (Pisces: Centropomidae). Proceedings of Animal Sciences, 1983; 92(6):415-422.

7. Heemstra PC, Randall JE. FAO species catalogue. Vol. 16. Groupers of the world (Family Serranidae, Subfamily Epinephelinae). An annotated and illustrated catalogue of the grouper, rockcod, hind, coralgrouper and lyretail species known to date. FAO Fisheries Synopsis. FAO, Rome, 1993; 125(16):382.

8. Chen CP, Hsieh HL, Chang KH. Age and growth of the grouper, Epinephelus diacanthus (Cuvier et Valenciensis) in the waters of northern Taiwan. Bulletin of the Institute of Zoology Academia Sinica. 1980; 19(1):1-9.

9. Monkolprasit S, Sontirat S, Vimollohakarn S, Songsirikul T. Checklist of Fishes in Thailand. Office of Environmental Policy and Planning, Bangkok, Thailand, 1997, 353.

10. Ni IH, Kwok KY. Marine fish fauna in Hong Kong waters. Zoological Studies. 1999; 38(2):130-152.

11. Sluka RD, Lazarus S. Grouper (Pisces: Serranidae) relative abundance and diversity on the west coast of India Marine Biodiversity Records, page 1 of 3. \# Marine Biological Association of the United Kingdom. 2010; 3(e71):1-3.

12. Rao CA, Krishnan L. Studies on the reproductive biology of the female spiny cheekgrouper, Epinephelus diacanthus (Valenciennes, 1828). Indian Journal of Fisheries. 2009; 56(2):87-94.

13. Zacharia PU, Gupta AC. Mahadevaswamy HS. Exploitation of juveniles of the spinycheek grouper, Epinephelus diacanthus by the multi-day trawlers along Dakshina Kannada coast. Marine Fisheries Information Services, Technical and Extension Series. 1995; 139:5-8.

14. Manojkumar PP. Fishery of the spinycheek grouper, Epinephelus diacanthus (Valenciennes), off Calicut along the Malabar Coast. Journal of Marine Biological
Association India. 2005; 47(1):63-69.

15. Premalatha P. Fishery and biology of rock cods from the southwest coast of India. Indian Journal of Fisheries. 1989; 36(4):285-291.

16. Chakraborty SK. Age growth and stock assessment of Epinephelus diacanthus Bulletin Central Marine Fisheries Research Institute 1994; 47:130-133.

17. Chakraborty SK. Stock assessment of big eye croaker Pennahia macrophthalamus (Bleeker) (pisces/ Perciformes /Sciaenidae) from Bombay waters. Indian Journal of Marine Sciences, 1996; 25:316-319.

18. Chakraborthy SK, Vidyasagar KD. Growth, mortality and stock assessment of two perches-moon tail bull's eye Priacanthus hamrur Perciformes / Priacanthidae) and thornycheek grouper Epinephelus diacanthus (Perciformes / Serranidae) from Bombay waters. Indian Journal of Marine Science. 1996; 25(4):312-315.

19. James PSBR, Murthy VSR, Nammalvar P. Groupers and snappers of India, biology and exploitation. In: ArreguinSanchez F., Munro, J.L. and Pauly, D. (Eds.), Biology of fishes and culture of tropical groupers and snappers. ICLARM, Conference Proceedings, 1996; 48:106-135.

20. Chakraborty SK, Biradar RS, Jaiswar AK, Palaniswamy R. Population parameters of some commercially important fishery resources of Mumbai coast. Central Institute of Fisheries Education, Deemed University, Versova, Mumbai, 2005, 63.

21. Sivakami S, Seetha PK. Indescriminate destruction of juveniles of spiny cheek grouper Epinephelus diacanthus (Valenciennes) off Quilon, Kerala. Journal of the Marine Biological Association of India, 2006; 48(1):128-130.

22. Ranjeet K, Arunjith TS, Sureshkumar S, Harikrishnan M. Population structure and length-weight relationship of Epinephelus diacanthus from Ponnani, South India, 2015. International Journal of Fisheries and Aquatic Studies 2015; 2(5):151-154.

23. Mehanna SF, Al-Marzouqi A, Badria El-Siab. Stock Characteristics and Population Dynamics of the Spiny Cheek Grouper Epinephelus diacanthus (Valenciennes, 1828) from the Arabian Sea, Oman Turkish Journal of Fisheries and Aquatic Sciences. 2013; 13:127-132.

24. Abdulaziz Al-Marzouqi, Mikhail Chesalin, Said AlShajibi. Some Aspects on Distribution and Biology of the Spinycheek Grouper Epinephelus diacanthus (Valenciennes, 1828) from the Arabian Sea off Oman Journal of Biology, Agriculture and Healthcare. 2015; 5(18):39-49.

25. Pauly D. ELEFAN I, a basic program for the objective extraction of recruitment pattern from length - frequency data. Meeresforssch. 1981; 28(4):201-210.

26. Saeger J, Gaynailo FJ. A revised and graphics oriented version of ELEFAN I and II basic programs for use on HP/ 86/87 microcomputers. Technical Research Department of Marine Fisheries, 1986, 8.

27. Pauly D, Munro JL. Once more, on the composition of growth in fish and vertebrates. Fish byte. 1984; 2(1):21.

28. Pauly D. On the interrelationships between natural mortality, growth parameters and mean environmental temperature in 175 fish stocks. Journal du Conseil /Conseil Permanent International pour l'Exploration de la Mer. 1980; 39 (3):175-192.

29. Beverton RJH, Holt SO. A review of methods for estimating mortality rates in fish populations with special reference to source of bias in catch sampling. Rapp.P.V. 
Renn. Conseil permanent International pour l'Exploration de la Mer 1956; 140:67-83.

30. Gulland JA. The fish resources of ocean. West by fleet, Survey, Fishing News (Book) Ltd. FAO, 1971, 255.

31. Pauly D. Fish population dynamics in tropical waters: A manual for use with programmable calculators. ICLARM Stud. Rev., 8, International Centre for Living Aquatic Resources Management, Manila, Philippines, 1984, 325.

32. Ingles J, Pauly D. An atlas of the growth, mortality and recruitment of Philipine fishes.ICLARM Technical Report, 1984; 13:127.

33. Vivekanandan E. Stock assessment of tropical marine fishes. Indian Council of Agricultural Research, New Delhi, 2005, 115.

34. Hile R. Summary of investigations on the morphometry of the cisco, Leucichthys artedi (Le Sueur), in the Lakes of the Northern Highland, Wisconsin. Pap. Michigan Academy of Science, Arts, and Letters, 1936; 21:619634.

35. Le Cren ED. The length weight relationship and seasonal cycle in Gonad weight and condition in perch (Perca fluviatilia) Journal of Animal Ecology, 1951; 20:210210.

36. Silas EG. Exploratory fishing by R.V. Varuna. Bulletin Central Marine Fisheries Research Institute, Kochi, 1969; 12:53-66.

37. Talwar PK, Kacker RK. Commercial fishes of India, Culcutta, 1984, 997.

38. Joseph KM, Sulochanan P, John ME, Somavanshi VS, Nair KNV, Joseph A. Demersal fishery resources of Wadge Bank. Bulletin of Fishery Survey of India, 1987; 12:1-52.

39. De Bruin GHP, Russel BC, Bogusch A. FAO Species Identification Field Guide for Fishery Purposes. The Marine Fishery Resources of Sri Lanka. FAO, Rome, 1995, 400.

40. Abdessalaam TZS. Marine species of the Sultanate Oman: An identification guide. Ministry of Aquaculture and Fisheries, Marine Science and Fisheries Centre, Sultanate of Oman. Muscat Printing Press, 1995, 412.

41. Manojkumar PP, Ranjith L, Karuppasamy K, Kanthan KP. Fishery and population dynamics of Epinephelus malabaricus (Bloch \& Schneider, 1801) off Tuticorin, southeast coast of India. Journal of the Marine Biological Association of India. 2019; 61(1):26-30.

42. Sparre P, Venema SC. Introduction to tropical fish stock assessments part I - Manual F.A.O. Fisheries Technical Paper, 1993; 306:376.

43. Ramachandran S, Philip KP. Population dynamics of redtoothed triggerfish Odonus niger (Ruppell, 1836) along southwest coast of India. Journal of Marine Biological Association of India. 2010; 52(1):105-108.

44. Ramachandran S, Ali DM, Benjamin CV. Age, growth and maturity of brown stripe snapper Lutjanus vitta (Quoy \& Gaimard, 1824) from southwest coast of India. Journal of Marine Biological Association of India. 2013; 55(2):61-68.

45. Beverton RJH, Holt SJ. A review of the spans and mortality rates of fish in nature and their relation to growth and other physiological characteristics. In CIBA foundation, colloquia on ageing. The life span of animals, edited by G.E.W. Wolsteholme and M.O. Connor, London. Churchill, 1959; 5:142-180.

46. Edwards RRC, Shaher S. The biometrics of marine fishes from the Gulf of Aden. Fishbyte. 1991; 9(2):27-29.

47. Abdurahiman KPT, Harishnayak PU, Zacharia KS. Mohamed. Length-weight relationship of commercially important marine fishes and shellfishes of the southern coast of Karnataka, India. NAGA, World Fish Center Quarterly. 2004; 27:1-2.

48. Ramachandran S, Philip KP, Narayanan M, Tharumar Y. Distribution and some biological aspects of grub fish Parapectis alboguttata (Gunther) in south west coast of India. Indian Journal of Fisheries. 2002; 49(2):205-207.

49. Fawzy AB, Soliman FM. Length weight relationship, relative condition and food and feeding habits of the goat fish Upenus sulphureus in safaga bay of Red sea. Journal of Marine Biological Association of India, 1984; 26(1, 2):83-88

50. Hamsa, AKMS, Mohamad Kasim H. The perch fishery be traditional traps at Kilakarai (Gulf of mannar) and some aspects of biology of Lethrinus nebulosus (Forskal). In K. Rangarajan And P. Sam Bennett (eds) Bulletin of Central Marine Fisheries Research Institute, 1994; 47:98-405.

51. Qasim SZ. The biology of Blennius pholis (Teleostei). Proceedings Zoological Society. London. 1957; 128(2):161-208.

52. Gonzalez P, Oyarzún C. Biological index variability in Pinguipes chilensis Valenciennes, 1833 (Perciformes, Pinguipedidae): Are they correlated? Gayana. 2002; 66(2):249-253.

53. Hickling CF. The seasonal cycle in the Cornish Pilchard, Sardina pilchardus Walbaum; Journal of Marine Biological Society of U.K 1945; 26:115-138.

54. Maddock DM, Burton MPM. Gross and histological observations of ovarian development and related condition changes in American plaice, Journal of Fish Biology. 1999; 53:928-944. 